Article

\title{
Analysis of the Gene Expression Profile of Stromal Pro-Tumor Factors in Cancer-Associated Fibroblasts from Luminal Breast Carcinomas
}

\author{
Noemi Eiro ${ }^{1, *}$, Sandra Cid ${ }^{1}$, María Fraile ${ }^{1}{ }^{\mathbb{D}}$, Jorge Ruben Cabrera ${ }^{1}$, Luis O. Gonzalez $^{2}$ and \\ Francisco J. Vizoso ${ }^{1, *(\mathbb{D})}$ \\ 1 Unit Research, Fundación Hospital de Jove, Gijón, 33290 Asturias, Spain; sandra.cid.89@gmail.com (S.C.); \\ maria.fraile82@gmail.com (M.F.); jorge.ruben.cabrera@gmail.com (J.R.C.) \\ 2 Department of Pathological Anatomy, Fundación Hospital de Jove, Gijón, 33290 Asturias, Spain; \\ a.patologica2@hospitaldejove.com \\ * Correspondence: noemi.eiro@gmail.com (N.E.); investigacion@hospitaldejove.com (F.J.V.); \\ Tel.: +34-985-320-050 (ext. 84216) (F.J.V.); Fax: +34-985-315-710 (F.J.V.)
}

Received: 1 September 2020; Accepted: 22 October 2020; Published: 23 October 2020

\begin{abstract}
Luminal tumors are the most frequent type of breast carcinomas showing less tumor aggressiveness, although heterogeneity exists in their clinical outcomes. Cancer-associated fibroblasts (CAFs) are a key component of the tumor stroma which contribute to tumor progression. We investigated by real-time PCR the gene expression of 19 factors implicated in tumor progression. Those factors included the calcium-binding protein S100A4, several growth factors (FGF2, FGF7, HGF, PDGFA, PDGFB, TGF $\beta$, VEGFA, and IGF2), and we also studied inflammatory cytokines (IL6 and IL8), chemokines (CCL2, CXCL12), important proteases (uPA, MMP2, MMP9 and MMP11), the nuclear factor $\mathrm{NF} \times \mathrm{B}$, and the metalloprotease inhibitor TIMP1, from luminal A and luminal B breast carcinoma CAFs. We performed a similar analysis after co-culturing CAFs with MCF-7 and MDA-MB-231 breast cancer cell lines. MMP-9 and CCL2 gene expressions were higher in CAFs from luminal B tumors. We also found different patterns in the induction of pro-tumoral factors from different CAFs populations co-cultured with different cancer cell lines. Globally, CAFs from luminal B tumors showed a higher expression of pro-tumor factors compared to CAFs from luminal A tumors when co-cultured with breast cancer cell lines. Moreover, we found that CAFs from metastatic tumors had higher IGF-2 gene expression, and we detected the same after co-culture with cell lines. Our results show the variability in the capacities of CAFs from luminal breast carcinomas, which may contribute to a better biological and clinical characterization of these cancer subtypes.
\end{abstract}

Keywords: cancer associated fibroblasts; tumor stroma; breast cancer; MMP11; IGF2

\section{Introduction}

Breast cancer is a heterogeneous disease. Clinically, breast cancers are categorized into four subtypes based on their intrinsic characteristics of cancer cells to facilitate targeted therapy. Immunohistochemical determinations of estrogen receptor (ER), progesterone receptor (PR), human epidermal growth factor receptor 2 (HER2), and Ki67 status are used to categorize these tumors [1-3]. In accordance with the more recent criteria [4], breast cancers are classified as: (1) luminal A (ERand/or PR-positive, HER2-negative); (2) luminal B (ER- and/or PR-positive, HER2-positive or Ki67 > 20\%); (3) HER2-enriched (HER2 amplified, ER- and PR-negative); and (4) triple-negative (ER-, PR-, and HER2-negative) subtypes.

Prognosis and survival are different depending on these subtypes [3]. Luminal tumors, the most frequent (accounting for 50-60\% of breast cancers) [5], are associated with the most favorable prognoses, 
while HER2-overexpressing and triple-negative tumors are associated with worst prognoses [6,7]. However, a biological heterogeneity exists in luminal tumors, and numerous patients with these tumors died of relapsed disease. For this reason, novel markers to improve prognosis and to decide therapeutic strategies are required.

Tumors are complex tissues composed of a heterogeneous mixture of cells, including cancer-cells and stromal cells. It is known that characteristics of stromal cells may dictate tumor outcome in breast cancer [8-11]. Cancer associated fibroblasts (CAFs) constitute the principal component of the tumor stroma. CAFs display a high proliferation rate and show capacity to facilitate tumor progression by degrading and remodeling the extracellular matrix (ECM), activating the epithelial mesenchymal transition (EMT), promoting an angiogenic shift, inducing a metabolic reprogramming toward a reverse Warburg phenotype, or stem cell trait achievement, compared with normal fibroblasts [12-15]. CAFs promote these actions by the secretion of growth factors and cytokines that influence the epithelium behavior [16-19]. In this context, CAFs can activate the NFkB signaling pathway to evoke a pro-inflammatory response, and through the secretion of IL- $1 \beta$, IL- 6, IL-8, and SDF- 1 , induce the recruitment of immune cells [20,21].

In the present study, we have investigated the gene expression of 19 factors implicated in tumor progression in CAFs from luminal breast carcinomas, and their variation after co-culture with MCF-7 and MDA-MB-231 breast cancer cell lines. Those factors were: the calcium-binding protein S100A4, several growth factors (FGF2, FGF7, HGF, PDGFA, PDGFB, TGF $\beta$, VEGFA, and IGF2), and we also studied inflammatory cytokines (IL6 and IL8), chemokines (CCL2, CXCL12), important proteases (uPA, MMP2, MMP9, and MMP11), the nuclear factor NFkB, and the metalloprotease inhibitor TIMP1.

\section{Material and Methods}

\subsection{Patient Selection and Their Characteristics, and Tissue Specimen Handling}

This study is a non-randomized prospective research which includes 19 women with a histological confirmed diagnosis of invasive breast carcinoma of luminal type. We selected consecutive cases of $\mathrm{T} 1$ or $\mathrm{T} 2$ invasive ductal carcinoma of luminal type with sufficient tissue for cell culture, during the period between July 2011 and August 2013, who underwent for a tumor resection as their first therapeutic approach. The exclusion criteria were: prior history of malignant tumor, excluding non-melanoma skin cancer, uterine cervix cancer in situ, ductal carcinoma in situ, or lobular carcinoma in situ of breast cancer, and a history of having received any type of therapy prior to surgery. Table 1 shows characteristics of the 19 patients with invasive breast carcinoma, all included in the analyses performed in this study and classified as luminal A (ER- and/or PR-positive, HER2-negative) or luminal B (ER- and/or PR-positive, HER2-positive or Ki67 > 20\%).

During the follow-up period, a total of 6 patients developed distant metastases. The follow-up period was 43 months for patients with recurrence and 58 months for patients without. Women were treated according to the guidelines used in our Institution (Fundación Hospital de Jove). Before the evaluation of tumor samples, all patients gave their written informed consent. The study adhered to National regulations and was approved by the Fundación Hospital de Jove Ethics and Investigation Committee. 
Table 1. Clinicopathological characteristics of the 20 patients with invasive breast carcinoma.

\begin{tabular}{|c|c|c|c|}
\hline Characteristics & $\begin{array}{c}\text { Luminal A } \\
N^{\circ}(\%)\end{array}$ & $\begin{array}{c}\text { Luminal B } \\
\mathrm{N}^{\circ}(\%)\end{array}$ & $p$ Value \\
\hline All patients & 7 & 12 & \\
\hline Median age (years) & & & 0.515 \\
\hline$<62$ & $4(57.1 \%)$ & $5(41.7 \%)$ & \\
\hline$>62$ & $3(42.9 \%)$ & $7(58.3 \%)$ & \\
\hline \multicolumn{4}{|l|}{ Tumor size } \\
\hline $\mathrm{T} 1$ & $3(42.9 \%)$ & $1(8.3 \%)$ & \\
\hline $\mathrm{T} 2$ & $4(57.1 \%)$ & $10(83.4 \%)$ & \\
\hline T3 & $0(0.0 \%)$ & $1(8.3 \%)$ & \\
\hline Histological grade & & & 0.082 \\
\hline Well differentiated (I) & $2(28.6 \%)$ & $0(0 \%)$ & \\
\hline Moderately differentiated (II) & $4(57.1 \%)$ & $6(50.0 \%)$ & \\
\hline Poorly differentiated (III) & $1(14.3 \%)$ & $6(50.0 \%)$ & \\
\hline Nodal status & & & 0.960 \\
\hline Negative & $3(42.9 \%)$ & $5(41.7 \%)$ & \\
\hline Positive & $4(57.1 \%)$ & $7(58.3 \%)$ & \\
\hline Estrogen receptors & & & - \\
\hline Negative & $0(0 \%)$ & $0(0 \%)$ & \\
\hline Positive & $7(100 \%)$ & $12(100 \%)$ & \\
\hline Progesterone receptors & & & 0.253 \\
\hline Negative & $0(0 \%)$ & $2(16.7 \%)$ & \\
\hline Positive & $7(100 \%)$ & $10(83.3 \%)$ & \\
\hline HER2 & & & 0.149 \\
\hline Negative & $7(100 \%)$ & $9(75.0 \%)$ & \\
\hline Positive & $0(0 \%)$ & $3(25.0 \%)$ & \\
\hline Ki67 & & & 0.020 \\
\hline$<20 \%$ & $4(57.1 \%)$ & $1(8.3 \%)$ & \\
\hline$\geq 20 \%$ & $3(42.9 \%)$ & $11(91.7 \%)$ & \\
\hline
\end{tabular}

Chi-square test applied.

\subsection{Cell Lines}

The estrogen-independent human breast cancer cell line MDA-MB-231, and the estrogendependent human breast cancer cell line MCF-7, were both purchased from the American Type Culture Collection (ATCC, Rockville, MD, USA).

The MCF-7 cell line was cultured in DMEM/F-12 (Lonza, Visp, Switzerland), and the MDA-MB-231 cell line was maintained in high glucose DMEM (Sigma, St. Louis, MO, USA). Both media were supplemented with 10\% FBS (PAA, North Darmouth, MA, USA) and the antibiotic mixture 1\% penicillin-streptomycin solution (Gibco, Paisley, UK).

\subsection{Primary Cell Culture}

Tumor samples were cut into $1 \mathrm{~mm}^{3}$ pieces and enzymatically dissociated in DMEM/F-12 supplemented with $10 \%$ FBS, $1 \%$ penicillin-streptomycin solution, and $1 \mathrm{mg} / \mathrm{mL}$ collagenase A (Roche, Hertfordshire, UK) at $37^{\circ} \mathrm{C}$ for $48 \mathrm{~h}$.

After enzymatic digestion, the suspension obtained was centrifuged at $400 \times g$ for $5 \mathrm{~min}$. Cell pellet was resuspended and cultured in DMEM/F-12 supplemented with $10 \% \mathrm{FBS}, 1 \%$ penicillin-streptomycin solution, $5 \mu \mathrm{g} / \mathrm{mL}$ insulin (Gibco), $1 \mu \mathrm{g} / \mathrm{mL}$ hydrocortisone (Sigma), and $5 \mathrm{ng} / \mathrm{mL}$ EGF (Invitrogen, Carlsbad, CA, USA). Cell cultures exhibited, predominantly, fibroblast morphology after three or four passages. Fibroblast culture purity was analyzed by flow-cytometry (Figure 1) using the antibody CD90 clone AS02 (Dianova, Hamburg, Germany) incubated at 1:50 $(4 \mu \mathrm{g} / \mathrm{mL})$ for $45 \mathrm{~min}$. After, two washes with PBS 1X, cells were incubated with the secondary antibody (FITC, R \& D Systems, Minneapolis, MN, USA, ref.: 0103) for $30 \mathrm{~min}$. CD90 clone AS02 antibody specificity was confirmed by immunohistochemistry before being used on study samples [19]. Also, we analyzed the expression 
of CD34 (555822, BD Pharmingen, San Diego, CA, USA), which is expressed by hematopoietic stem cells/progenitors as well as by a multitude of other non-hematopoietic cell types, including epithelial progenitors and vascular endothelial progenitors.

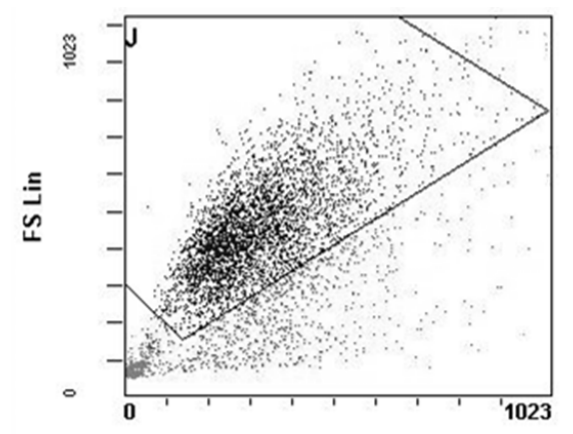

A

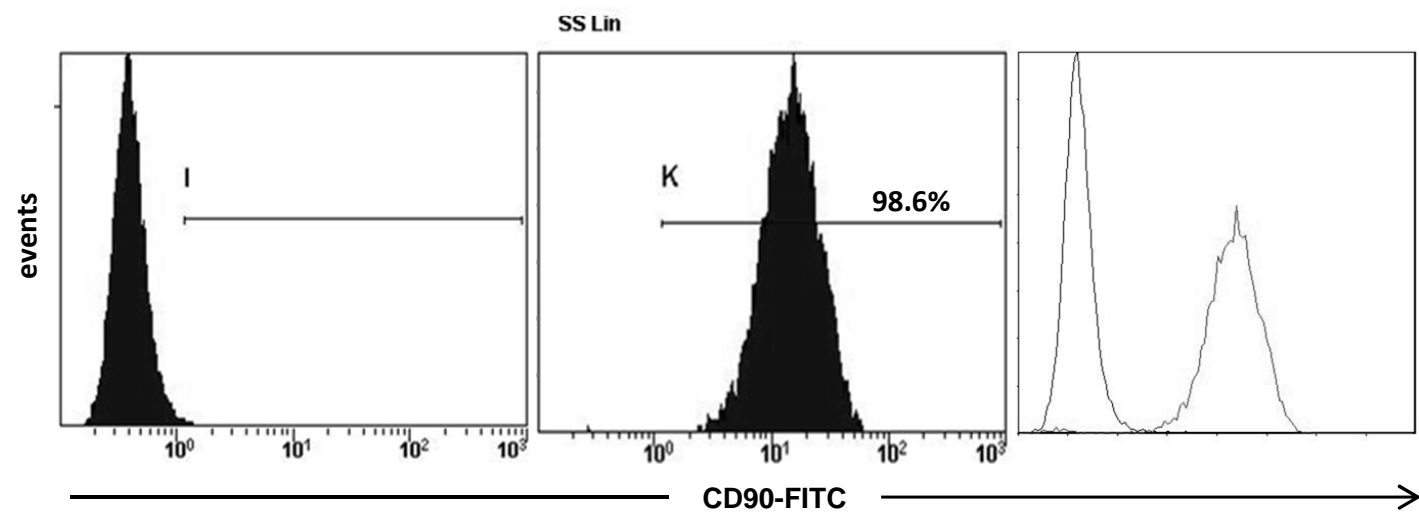

B

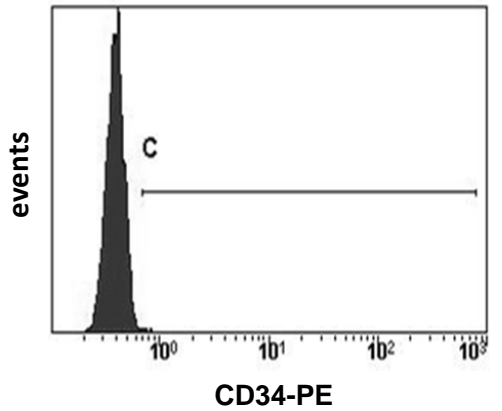

Figure 1. Representative example of flow-cytometry analysis of fibroblast population. At the top it shown a selection of cell population depending on the size and the cellular complexity (SS). (A) Negative control, positive expression for CD90 and the overlay. For this analysis all 19 patients were included.

(B) Negative CD34 expression in a positive CD90 fibroblast population.

\subsection{Co-Culture Experiments}

Transwell 24-well plates were used to perform co-cultures of fibroblasts with breast cancer cell lines. Fibroblast cells were plated at $2 \times 10^{4}$ cells in the bottom of the wells, whereas breast cancer cell lines were seeded $\left(2 \times 10^{4}\right.$ cells $)$ in the $0.24 \mu \mathrm{m}$ pore size tissue culture inserts, which were introduced into the fibroblasts-containing wells later on. Cells were co-cultured for $72 \mathrm{~h}$ in DMEM/F-12 supplemented with 10\% FBS and 1\% penicillin-streptomycin solution. Then, RNA extraction was performed using the following protocol.

\subsection{Real Time-PCR}

"RNeasy Mini Kit" (Qiagen, Hilden, Germany) including the DNAse treatment was used according to the manufacturer's instructions for total RNA isolation. As described previously [19], the integrity 
and concentration of RNA was determined spectrophotometrically by using a NanoDrop Technologies device, (Wilmington, DE, USA). First strand cDNA was synthesized using the "Transcriptor First Strand cDNA Synthesis Kit" (Roche, Mannheim, Germany) following the manufacturer's instructions. The reverse transcription step was carried out using the following program: firstly, an incubation at $65^{\circ} \mathrm{C}$ during $10 \mathrm{~min}$ was performed to ensure denaturation of RNA secondary structures, and then, the reverse transcription reaction was performed as follows: $10 \mathrm{~min}$ at $25{ }^{\circ} \mathrm{C}, 60 \mathrm{~min}$ at $50{ }^{\circ} \mathrm{C}$, and $5 \mathrm{~min}$ at $85^{\circ} \mathrm{C}$.

Expressions of different factors were measured using RealTime ready custom panel plates (Roche). These custom-designed plates contained the specific primers and probes for the factors studied and for three reference genes (Table 2). The mRNA levels were measured in a LightCycler 480 II (Roche) with the following cycling conditions: $95^{\circ} \mathrm{C}$ for $10 \mathrm{~min}, 45$ cycles of $95^{\circ} \mathrm{C}$ for $10 \mathrm{~s}, 60{ }^{\circ} \mathrm{C}$ for $30 \mathrm{~s}$, and $72{ }^{\circ} \mathrm{C}$ for $1 \mathrm{~s}$.

Table 2. Factors analyzed and main roles.

\begin{tabular}{cccc}
\hline Gene Symbol & References & Gene Name & Main Role \\
\hline S100A4 & 110779 & S100 calcium binding protein A4 & Invasion \\
\hline TGF $\beta$ & 101210 & Transforming growth factor beta & Inflammation \\
\hline HGF & 108357 & Hepatocyte growth factor & Cell growth/Invasion \\
\hline FGF2 & 118274 & Fibroblast growth factor 2 (basic) & Angiogenesis \\
\hline FGF7 & 113109 & Fibroblast growth factor 7 & Cell growth/Invasion \\
\hline PDGFA & 110648 & Platelet-derived growth factor alpha & Angiogenesis \\
\hline PDGFB & 110713 & Platelet-derived growth factor beta & Angiogenesis \\
\hline uPA & 109571 & Urokinase-type plasminogen activator & ECM remodelling \\
\hline IL6 & 113614 & Interleukin 6 & Inflammation \\
\hline IL8 & 103136 & Interleukin 8 & Inflammation \\
\hline CXCL12 & 110618 & Chemokine (C-X-C motif) ligand 12 & Inflammation \\
\hline CCL2 & 141156 & Chemokine (C-C motif) ligand 2 & Inflammation \\
\hline NFkB & 100646 & Nuclear factor kappa B & Inflammation/Tumor growth \\
\hline MMP2 & 103899 & Matrix metalloproteases 2 & ECM remodelling \\
\hline MMP9 & 139820 & Matrix metalloproteases 9 & ECM remodelling \\
\hline MMP11 & 103163 & Matrix metalloproteases 11 & ECM remodelling \\
\hline TIMP1 & 103847 & Tissue inhibitor of metalloproteases 1 & ECM remodelling \\
\hline VEGFA & 140392 & Vascular endothelial growth factor A & Angiogenesis \\
\hline IGF2 & 113548 & Insulin-like growth factor 2 & Cell growth \\
\hline ACTB & 101125 & Actin, beta & - \\
\hline SDHA & 102136 & subunit A, flavoprotein & - \\
\hline
\end{tabular}

The expression was quantified using advanced relative quantification. In this method, the crossing point $(\mathrm{Cp})$ is automatically calculated using the LightCycler software as the first maximum of the second derivative of the curve. A combination of two housekeeping genes ( $\beta$-actin and SDHA (Succinate dehydrogenase subunit A)) as a normalization factor was used to minimize sample variability and to increase the accuracy and resolution of gene expression normalization.

\subsection{Immunohistochemistry}

To study the protein expression of IGF2, immunohistochemistry staining was performed on tissue sections of breast cancer using a TechMate TM50 autostainer (Dako, Glostrup, Denmark), a primary antibody against IGF2 (ab9574, Abcam, antigen retrieval pH6, incubation $1 \mathrm{~h}$ ) and the EnVision 
Detection kit (Dako). Sections were counterstained with hematoxylin, dehydrated with ethanol and permanently coverslipped, as previously described [19].

\subsection{Statistical Analysis}

All statistical analyses were performed using PASW Statistics 18. The Kolmogorov-Smirnov Test was used to determine whether sample data were normally distributed. As data were normally distributed, comparison between groups was performed with the Student's $t$ test. Survival curves were calculated with the Kaplan-Meier method and compared by the log-rank test. Differences were considered significant when the $p$-value $\leq 0.05$. The PASW Statistics program was used for all calculations.

\section{Results}

\subsection{Molecular Profile of CAFs}

We determined whether CAFs from luminal tumors presented phenotypic variability at their basal expression of several genes implicated in tumor progression (S100A4, FGF2, FGF7, HGF, PDGFA, PDGFB, TGF $\beta$, VEGFA, IGF2, IL6, IL8, CCL2, CXCL12, uPA, MMP2, MMP9, MMP11, NFkB, and TIMP1). CCL2 and MMP9 gene expressions were significantly higher in CAFs from luminal $B$ tumors compared to CAFs from luminal A tumors ( $p=0.003$ and $p=0.02$, respectively, Figure 2). However, we found no significant differences in other pro-tumoral factors between CAFs from these two tumor subtypes.
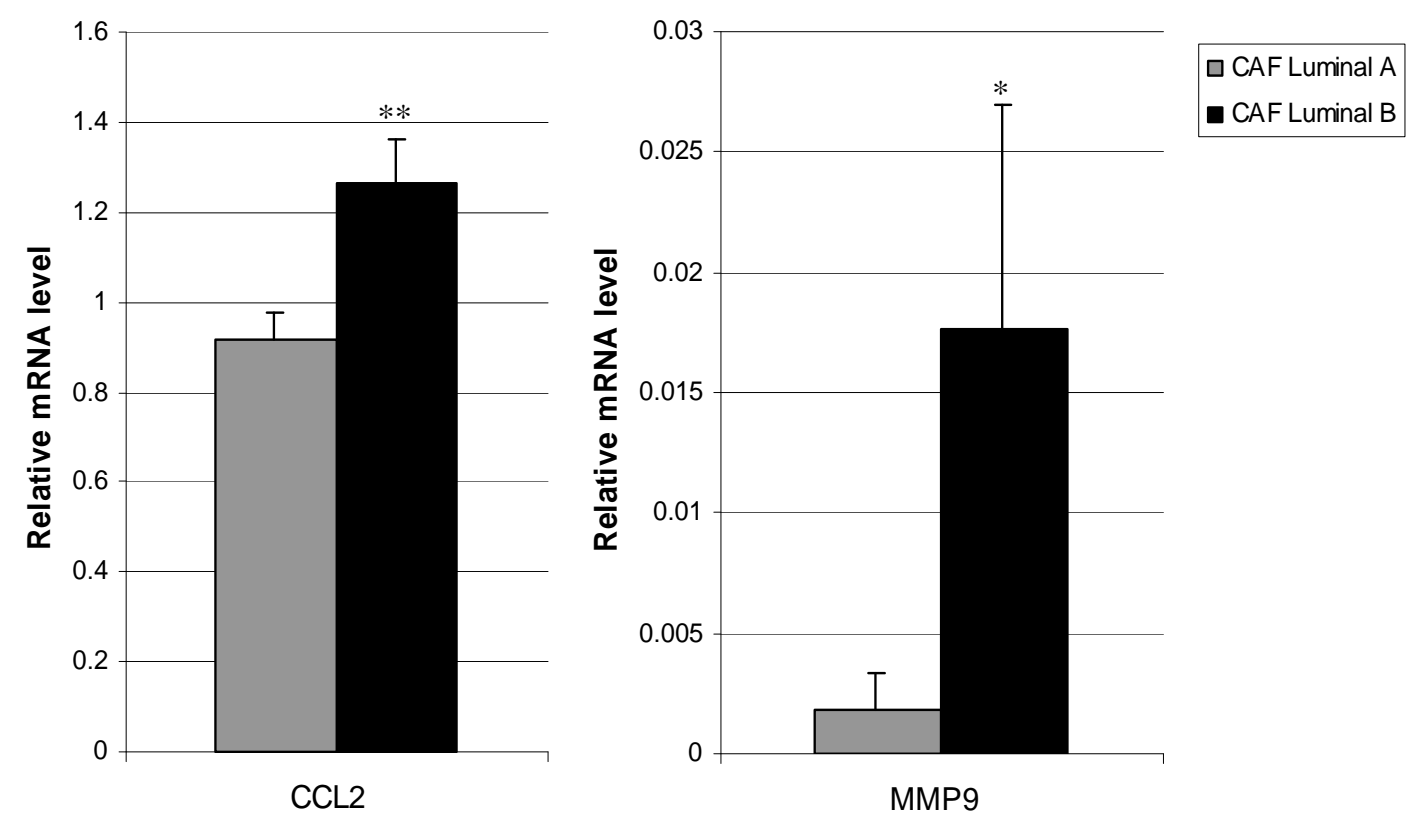

Figure 2. Real-time PCR analysis of factors assessed in CAFs from Luminal A and Luminal B breast cancer. Expression of CCL2 (left) and MMP9 (right). Data represent the mean \pm SD $\left({ }^{*} p \leq 0.05\right.$, ${ }^{* *} p \leq 0.001$ ). For this analysis, performed in triplicate, all 19 patients were included.

\subsection{Molecular Profile of CAFs Co-Culture with MCF-7 and MDA-MB-231 Cancer Cell Lines}

We next examined the effect of breast tumor cell lines over different CAFs from luminal A or luminal B subtypes. We found different patterns in the expression of pro-tumoral factors depending on the CAF's luminal type co-cultured with the different cancer cell lines. CAFs from luminal A tumors co-cultured with the luminal cell line MCF-7, showed an increase in VEGFA levels $(p=0.028)$ (Figure 3A), but a decrease in the gene expression of HGF $(p=0.028)$, CCL2 $(p=0.028), \operatorname{NFkB}(p=0.046)$, and MMP-9 $(p=0.028)$ (Figure 3A). CAFs from luminal B tumors co-cultured with MCF-7 showed a 
decrease in CCL2 $(p=0.003)$ and NFKB $(p=0.009)$ gene expression, while they showed an increased gene expression of other important pro-tumoral factors such as TGF $\beta(p=0.007)$, CXCL12 $(p=0.013)$, MMP-2 ( $p=0.039)$ and VEGF A $(p=0.003)$ (Figure 3B). When CAFs were co-cultured with the triple negative MDA-MB-231 cell line, CAFs from luminal A tumors showed an increased gene expression of MMP-2 and VEGFA ( $p=0.028$, for both) (Figure 3C), whereas CAFs from luminal B tumors showed an increased expression in VEGFA $(p=0.003), \operatorname{S100A4}(p=0.019), \operatorname{TGF} \beta(p=0.004), \operatorname{IL6}(p=0.049)$, and IL8 $(p=0.009)$, but a decrease of NFKB expression $(p=0.028)$ (Figure 3D). All together, these data suggest that CAFs from luminal B tumors showed, globally, a higher gene expression profile of stromal pro-tumoral factors when co-cultured with any one of these two breast cancer cell lines.

A

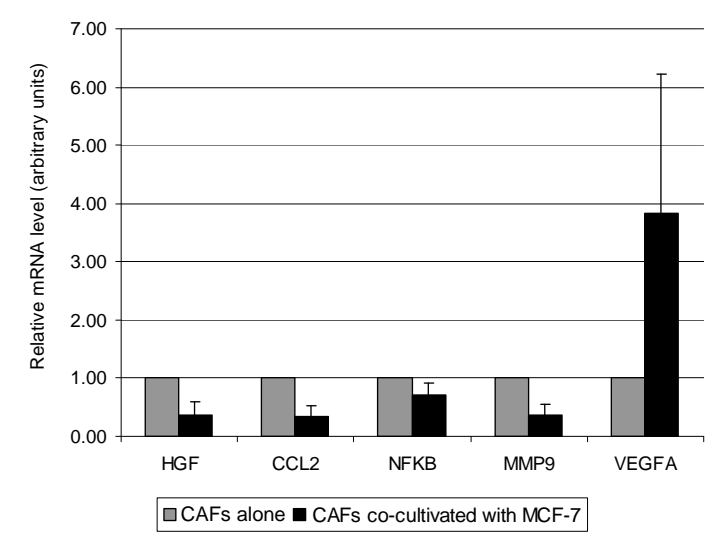

C

Luminal A

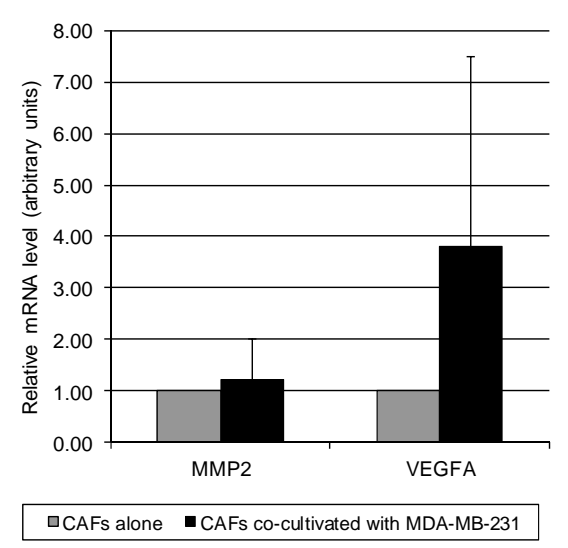

B

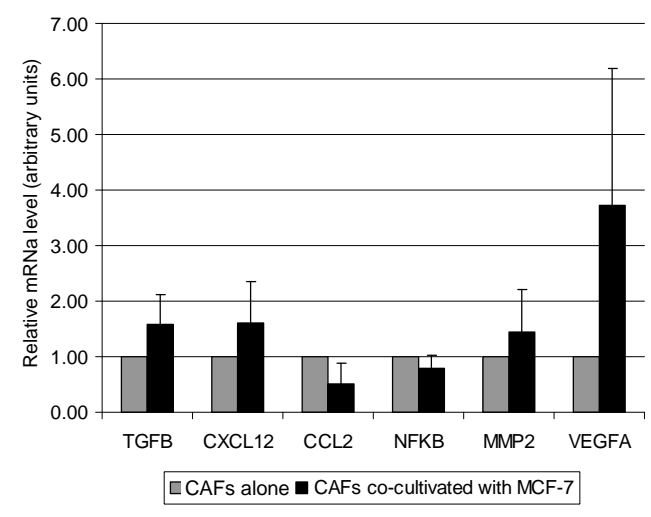

D

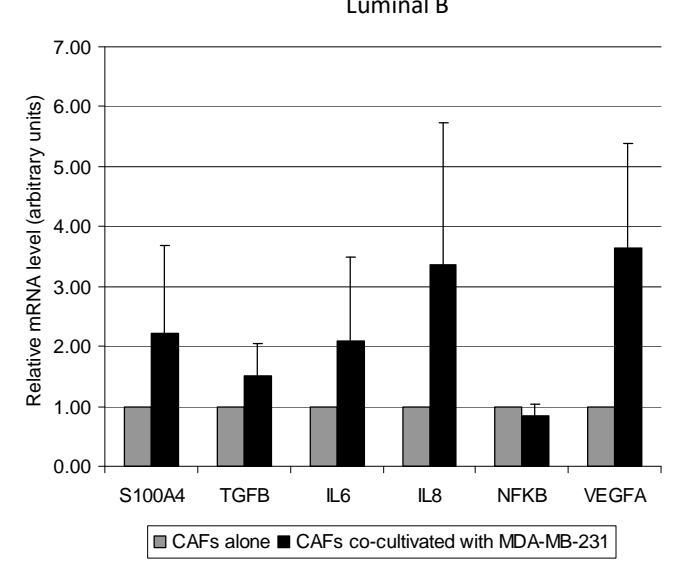

Figure 3. Real-time PCR analysis of factors assessed between: (A) CAFs from Luminal A tumors cultured alone or co-cultured with MCF-7, (B) CAFs from Luminal B tumors cultured alone or co-cultured with MCF-7, (C) CAFs from Luminal A tumors cultured alone or co-cultured with MDA-MB-231, (D) CAFs from Luminal B tumors cultured alone or co-cultured with MDA-MB-231. Data represent the mean \pm SD. Only factors with significant differential expression are represented. $p$ values are indicated in the text. Values are normalized to CAFs alone. For this analysis, performed in triplicate, all 19 patients were included.

\subsection{Relationship between CAFs' Molecular Profile and Development of Distant Metastasis}

We also compared the relapse-free survival period with the basal molecular profiling of CAFs. Six patients developed distant metastasis during the follow-up period: two patients with luminal A tumors and four with luminal B tumors. Then, we re-analyzed the gene expression of CAFs comparing those patients developing metastasis with the rest of patients. Interestingly, we found that high IGF2 gene expression (>median) in CAFs was significantly associated with a shortened relapse-free survival (Figure 4A). In addition, higher basal IGF2 gene expression was found in CAFs from metastasic 
tumors than in CAFs from non-metastasic tumors in all luminal tumors (Figure 4B), and especially, in luminal B tumors (Figure 4C). No significant data was obtained for luminal A tumors due to the low recurrence rate in this population and the small sample size. Finally, we also observed that higher IGF2 gene expression in CAFs from metastatic tumors remained increased after co-culture with MCF-7 or MDA-MB-231 (Figure 4D,E).

In order to confirm the protein expression of IGF2, we stained primary tumors tissue sections and observed the expression by fibroblast (Figure 5). However, we could not analyze all samples (no access to tissue block for all patients) and therefore we could not establish its concordance to metastasis development.
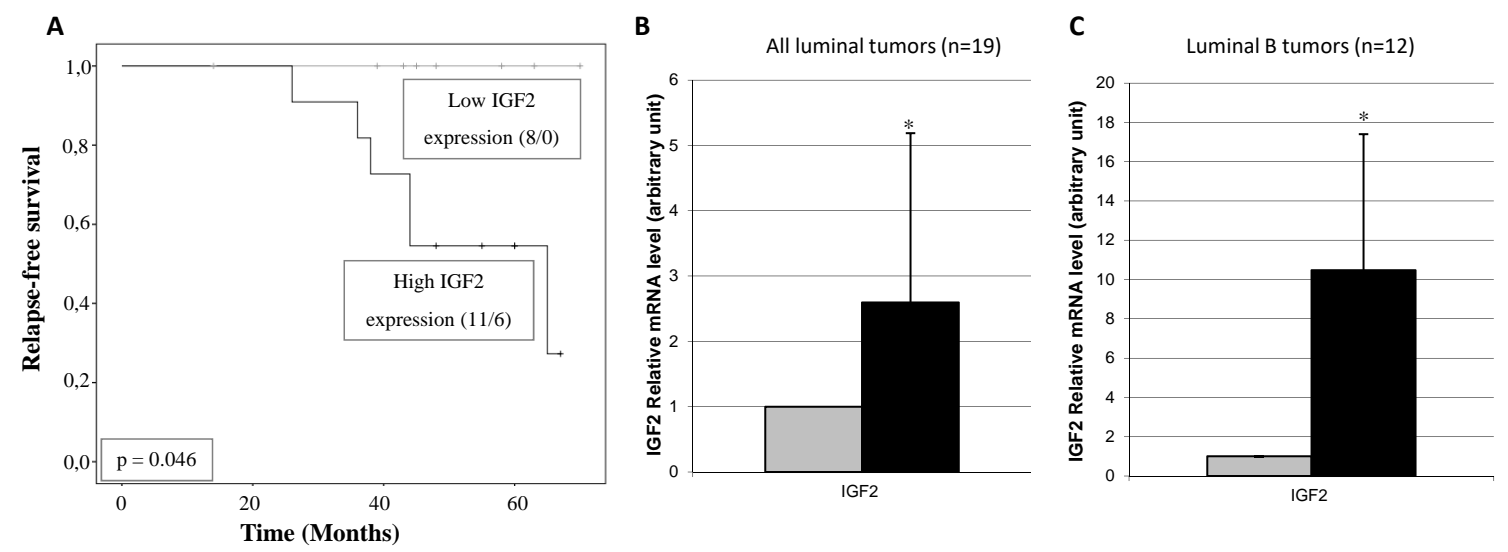

D

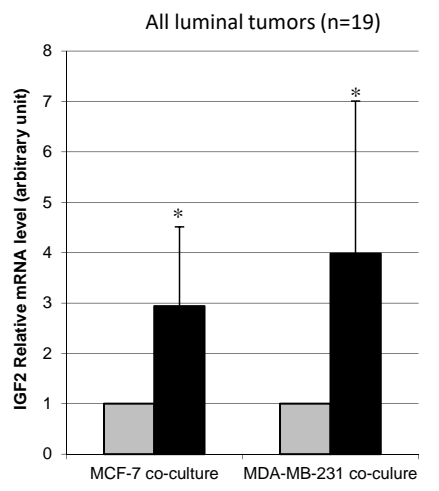

E
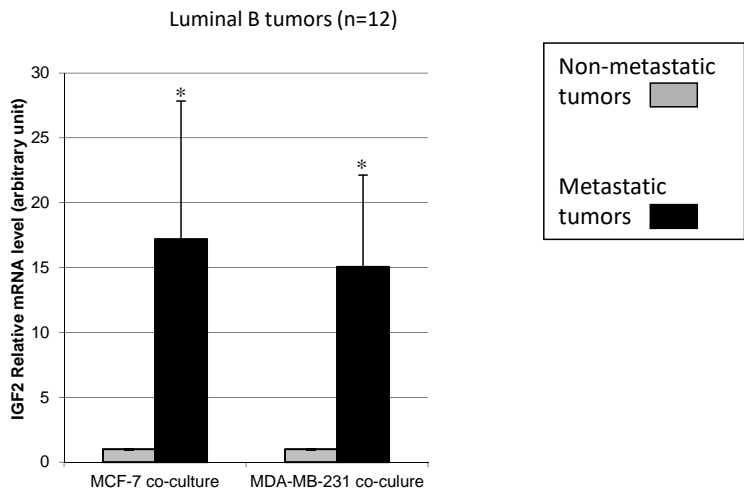

Figure 4. Prognostic significance of IGF2 expression studied in 19 patients with luminal breast carcinomas. (A) Kaplan-Meier survival curves for relapse-free survival as a function of IGF2 expression. The median value of IGF2 was taken as cut-off value. The ratio of number of events/total cases is indicated within parentheses. (B) Real-time PCR analysis of IGF2 assessed in CAFs from all of 19 luminal tumors (13 non-metastatic tumors and 6 metastatic tumors). (C) Real-time PCR analysis of IGF2 assessed in CAFs from 12 luminal B tumors (8 non-metastatic tumors and 4 metastatic tumors) * $p=0.08$. (D) Real-time PCR analysis of IGF2 assessed in CAFs from all of 19 luminal tumors after co-culture with MCF-7 or MDA-MB-231. (E) Real-time PCR analysis of IGF2 assessed in CAFs from 12 luminal B after co-culture with MCF-7 or MDA-MB-231. ${ }^{*} p<0.05$. For this analysis, performed in triplicate, all 19 patients were included. 

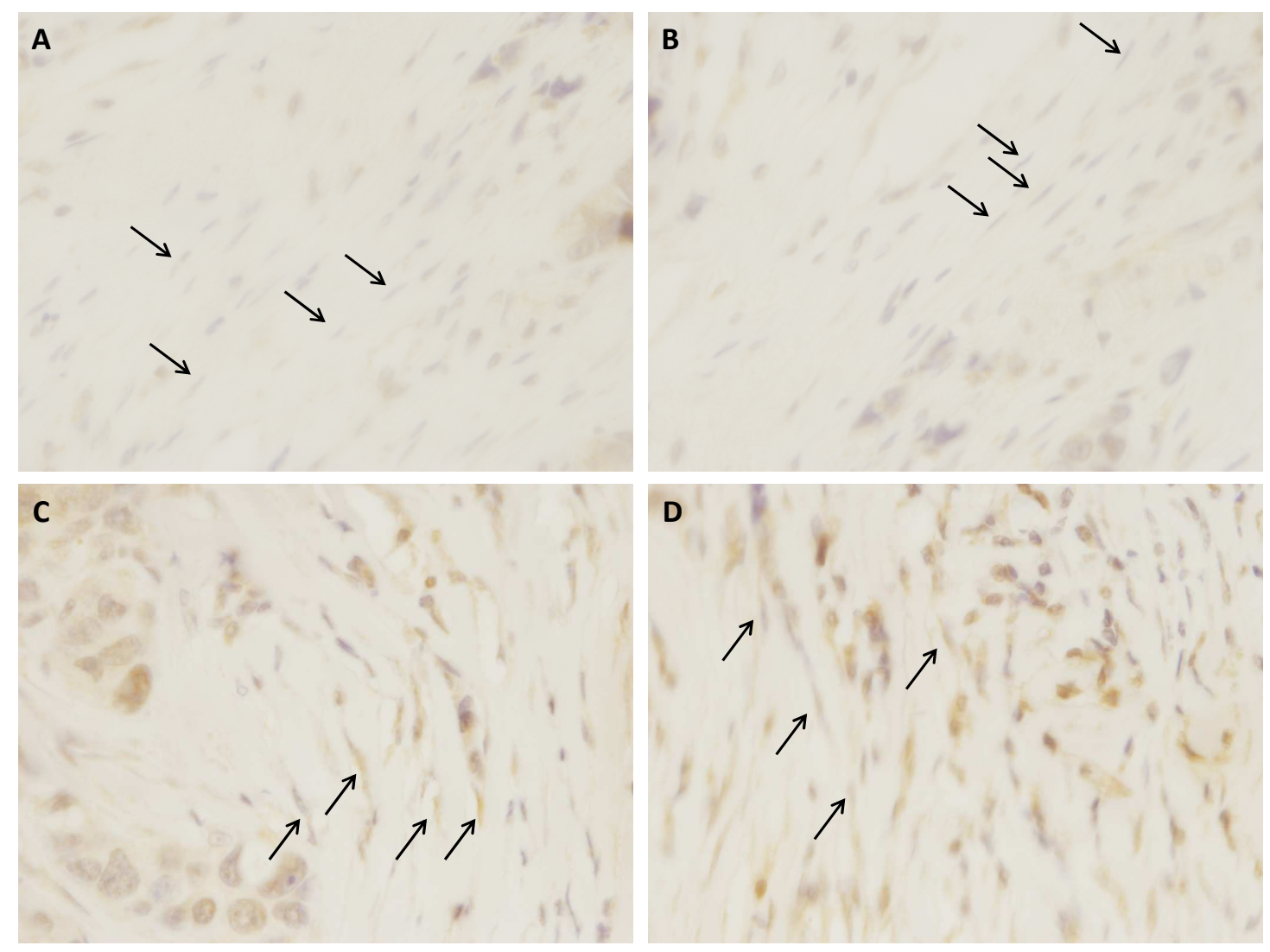

Figure 5. Representative examples of IGF2 (A,B) negative and (C,D) positive immunostaining in fibroblasts, corresponding to $(\mathbf{A}, \mathbf{B})$ a non-metastatic and $(\mathbf{C}, \mathbf{D})$ a metastatic luminal B breast cancer, respectively $(\times 400)$. Black arrows represent fibroblasts.

\section{Discussion}

Today, breast tumors are categorized based on cancer cell characteristics for their management. Four main intrinsic molecular subtypes of breast cancer (luminal A, luminal B, HER2-enriched and basal-like) have been established over the last 15 years. Each of these subtypes has different features, clinical behaviors, and treatment response profiles [22]. Luminal tumors, the most frequent type (accounting for $50-60 \%$ of breast cancers), are associated with the most favorable prognoses [6,7]. However, a biological heterogeneity exists in luminal tumors, and numerous patients with these tumors died of relapsed disease. Our results indicate that CAFs from luminal B tumors show more pro-tumor characteristics compared with CAFs from luminal A tumors, which provide evidence of a possible contribution of the stroma to the different biological and clinical behavior between these tumors. Luminal A breast cancers are associated with a most favorable short-term prognosis due to its positive response to endocrine therapy [23]. Luminal B tumors are recognized to have a more aggressive clinical behavior and unfavorable prognosis compared with luminal A tumors [24,25]. In fact, many of the luminal $\mathrm{B}$ tumors are $\mathrm{ER}^{+} / \mathrm{HER}^{-} /$high Ki-67. However, expression profiles also classify the $\mathrm{ER}^{+} / \mathrm{HER}^{+}$ tumors as luminal $\mathrm{B}$, and these patients receive a different therapy regimen (that incorporates targeted anti-HER2 therapy) compared to other luminal B breast cancer [26]. In addition, according to the 2013 St. Gallen Consensus, the diagnosis of a portion of patients with the luminal A subtype with poor prognosis was changed to the luminal B subtype, which was determined based on ER positivity, HER2 negativity, Ki67 expression $>14 \%$, and PgR expression $<20 \%$ [4,27]. Thus, luminal B breast tumors (that accounted for nearly $40 \%$ of all breast cancers [28]) constitute the most heterogeneous molecular subtype at the clinical and molecular levels. Unfortunately, the immunohistochemistry of the luminal B subtype, based on intrinsic genetics characteristics from cancer cells, remains poorly defined, and it has 
now become a paramount importance to find new markers capable of segregating luminal tumors into clinically meaningful subgroups that may be used clinically to guide patient management. With this in mind, in the present study, we have tried to identify CAFs populations differing in their pro-tumor capabilities in these luminal tumors.

In the present study, we found variability in the gene expression of factors implicated in tumor progression in CAFs from luminal breast carcinomas (Table 1), and after co-culture with MCF-7 and MDA-MB-231 breast cancer cell lines, depending whether those CAFs are from luminal A or B tumors. CAFs from luminal B tumors showed higher gene expression of MMP-9 and CCL2 compared to CAFs from luminal A tumors. These findings are relevant if we consider that MMP-9 (also known as Gelatinase B) is related to tumor invasion and metastasis by its capacity to degrade the type IV collagen found in basement membranes [29], and to induce angiogenesis [30]. Likewise, MMP-9 has been associated with tumor aggressiveness and/or poor prognostic in patients with breast cancer [31-33]. On the other hand, CCL2 (monocyte chemoattractant protein 1, MCP1) is a chemokine that exerts a potent chemotactic, stimulatory, and mitogenic effects on mononuclear cells [34]. High levels of CCL2 in the tumor microenvironment [35], as well as high circulating concentrations of this chemokine, have been associated with poor prognosis in breast carcinoma patients [36]. CCL2 also stimulates the migration of mammary carcinoma cell lines [37], and mediates the recruitment of specific monocyte populations that support the establishment of metastatic disease [38].

Especially relevant were our findings showing that different CAFs populations differentially expressed pro-tumor factors depending on co-cultured cancer cell lines. Thus, after co-culture with the luminal cell line MCF-7, CAFs from luminal A tumors showed an increase in VEGFA levels, but a decreased expression levels of other pro-tumor genes (HGF, CCL2, NFKB, and MMP-9) while CAFs from luminal B tumors although showed decreased levels of CCL2 and NFKB gene expression, but increased gene expression of other important pro-tumor factors like TGF $\beta$, CXCXL12, MMP-2, and VEGF A. Likewise, different patterns of gene expression were found in CAFs from Luminal A tumors, with increased expression of MMP-2 and VEGFA, or CAFs from luminal B tumors, with increased levels of VEGFA, S100A4, TGF $\beta$, IL6, and IL8, but decreased levels of NFKB, after being co-cultured with the cell line MDA-MB-321.

In general, CAFs from luminal B tumors showed higher expression of pro-tumor factors when co-cultured with breast cancer cell lines, which is in accordance with the fact that these tumors are associated with higher tumor aggressiveness. These overexpressed factors are of importance promoting several biological aspects of tumor progression. TGF $\beta$ is a well-known cytokine that induces malignant mammary epithelial cell to undergo EMT, leading to the acquisition of highly migratory, invasive and metastatic phenotypes [39]. It has been also described that TGF $\beta$ can induce the expression of different proteins, such as growth factors, cytokines, and ECM proteins in CAFs, which promote tumor development in the adjacent epithelium [40]. CXCL12 is a highly pleiotropic chemokine, influencing a variety of biological processes through the interaction with its receptors CXCR4 and CXCR7. CXCL12-CXCR4 signaling has been shown to play a role in tumor growth, invasion, angiogenesis and bone marrow cell recruitment [41-44]. In line with this, it has been demonstrated that co-implantation of tumor cells with fibroblasts expressing CXCL12 enhances tumor growth [41] and CXCL12 overexpression has been linked to increased metastasis and poor prognosis [45]. In addition, a number of different agents have been used to block the CXCL12-CXCR4 interaction to inhibit metastasis [46-48].

MMP-2 (Gelatinase A) together with MMP-9 (Gelatinase-B) are related to tumor invasion and metastasis by their special capacity to degrade type IV collagen in basement membrane [29], and to induce angiogenesis [30]. MMP-2 production increased during the early phase of breast cancer [49], but also high levels of MMP-2 have been related to poor outcome in breast carcinomas [50]. VEGFA is a potent regulator of angiogenesis and thereby involved in the development and progression of solid tumors, such as breast cancer [51-53]. S100A4, a member of the S100 calcium-binding protein superfamily, has been described as a key player in promoting metastasis, acting as an angiogenic 
factor, inducing cell motility, and increasing the expression of MMPs [54-56]. In fact, elevated levels of the calcium-binding protein S100A4 have been associated with poor patient survival in breast cancer patients and to induce metastasis in rodent models [57,58].

Interestingly, we have observed high expression levels of IL6 and IL8 in CAFs from luminal B tumors after co-culture with MDA-MB-231 cells. Previous reports showed that both cytokines are important to maintain the aggressiveness of MDA-MB-231 cells, a highly tumorigenic cell line which appears to be devoid of stemness-related features [59]. In addition, clinical studies have showed that both high levels of IL-6 or IL-8 have been associated with breast cancer recurrence [60-63]. In addition, several strategies to disrupt IL-6 signaling [64] or IL-8 signaling [65], in vitro or in vivo, significantly reduce tumor growth and metastasis in breast cancer cells.

Together, these gene expression data may to contribute to a better characterization of tumor stroma of luminal breast carcinomas.

Finally, we reclassified the CAFs gene expression analysis considering patients developing or not distant metastasis during the follow-up period. An obvious limitation of the present study is the reduced number of patients who developed distant metastasis during the follow-up period. Nevertheless, and interestingly enough, we have observed that CAFs from metastatic luminal tumors had the highest IGF-2 gene expression, either in basal levels or after being co-cultured with MCF-7 or MDA-MB-231 cell lines. These findings seem to be in agreement with previous data revealing that IGF2, which is overexpressed in a wide spectrum of human cancers, is associated with more aggressive tumors [66,67] and with a poor prognosis [68]. IGF-2 promotes excessive growth and anti-apoptotic effects in cancer cells [69]. In fact, it has been shown that IGF-2 signaling is important to stimulate the proliferation of MCF-7 [70,71] and MDA-MB-231 [72]. In addition, IGF-2 has been recently implicated in a positive feedback circuit as a critical mechanism to increase stemness and maintain breast cancer cells [73]. More importantly, it has been suggested that CAFs derived from breast metastatic tumors have increased protumorogenic properties due to the increased expression of IGF2 [74]. On the other hand, there are several lines of evidence linking IGF signaling and luminal tumors. In one large follow-up study on breast cancer in postmenopausal women, serum levels of IGF-2, but not IGF-1, were positively associated with oestrogen receptor-positive breast cancer risk [75]. Likewise, it has been reported that both the co-expression [76] and interactions [77] of IGF1R (receptor for IGF-1 and IGF-2) and ER signaling systems suggest a role for the IGF1R network in the resistance to endocrine therapy [76,78]. It is also remarkable that IGF-2 is known to play an important role during fetal growth and development, and its expression in malignant tumors might implicate a more primitive cellular phenotype [79]. Taken together, our results suggest that IGF-2 expression may be a potential useful marker of tumor aggressiveness and poor prognosis in luminal tumors.

In summary, our data may contribute to a better biological characterization of the interaction between cancer cells and tumor stroma in luminal breast carcinomas. In this way, our results allow us to consider that, among the complex array of soluble factors produced by CAFs, it could arise possible new prognostic markers and therapeutic targets for luminal breast cancer.

Author Contributions: Conceptualization: N.E., M.F., L.O.G., and F.J.V.; Data curation: N.E., M.F., J.R.C., L.O.G., and F.J.V.; Formal analysis: N.O., S.C., M.F., and L.O.G.; Investigation: N.E., S.C., and M.F.; Methodology: N.E. and S.C.; Project administration: N.E. and F.J.V.; Resources: L.O.G. and F.J.V.; Writing一original draft: N.E., S.C., M.F., and F.J.V; Writing-review \& editing: N.E., J.R.C., and F.J.V. All authors have read and agreed to the published version of the manuscript.

Funding: This study was supported by grants to F.J.V from Instituto de Salud Carlos III (PI17/02236) and co-funded by European Union (ERDF/ESF, “Investing in your future”) and by Fundación para la Investigación en Células Madre Uterinas (FICEMU) to FV. SC was recipient of a fellowship financed by the Gobierno del Principado de Asturias "Severo Ochoa" PhD Program under Grant BP14-128.

Conflicts of Interest: The authors declare no conflict of interest 


\section{References}

1. Goldhirsch, A.; Wood, W.C.; Coates, A.S.; Gelber, R.D.; Thurlimann, B.; Senn, H.J.; Panel, m. Strategies for subtypes-dealing with the diversity of breast cancer: Highlights of the St. Gallen International Expert Consensus on the Primary Therapy of Early Breast Cancer 2011. Ann. Oncol. 2011, 22, 1736-1747. [CrossRef] [PubMed]

2. Perou, C.M.; Sorlie, T.; Eisen, M.B.; van de Rijn, M.; Jeffrey, S.S.; Rees, C.A.; Pollack, J.R.; Ross, D.T.; Johnsen, H.; Akslen, L.A.; et al. Molecular portraits of human breast tumours. Nature 2000, 406, 747-752. [CrossRef] [PubMed]

3. Montagna, E.; Bagnardi, V.; Rotmensz, N.; Viale, G.; Cancello, G.; Mazza, M.; Cardillo, A.; Ghisini, R.; Galimberti, V.; Veronesi, P.; et al. Immunohistochemically defined subtypes and outcome in occult breast carcinoma with axillary presentation. Breast Cancer Res. Treat. 2011, 129, 867-875. [CrossRef] [PubMed]

4. Goldhirsch, A.; Winer, E.P.; Coates, A.S.; Gelber, R.D.; Piccart-Gebhart, M.; Thurlimann, B.; Senn, H.J.; Panel, m. Personalizing the treatment of women with early breast cancer: Highlights of the St Gallen International Expert Consensus on the Primary Therapy of Early Breast Cancer 2013. Ann. Oncol. 2013, 24, 2206-2223. [CrossRef] [PubMed]

5. American Cancer Society. Breast Cancer Facts \& Figures 2013-2014; American Cancer Society: Atlanta, GA, USA, 2013.

6. Sorlie, T.; Perou, C.M.; Tibshirani, R.; Aas, T.; Geisler, S.; Johnsen, H.; Hastie, T.; Eisen, M.B.; van de Rijn, M.; Jeffrey, S.S.; et al. Gene expression patterns of breast carcinomas distinguish tumor subclasses with clinical implications. Proc. Natl. Acad. Sci. USA 2001, 98, 10869-10874. [CrossRef] [PubMed]

7. Carey, L.A.; Perou, C.M.; Livasy, C.A.; Dressler, L.G.; Cowan, D.; Conway, K.; Karaca, G.; Troester, M.A.; Tse, C.K.; Edmiston, S.; et al. Race, breast cancer subtypes, and survival in the Carolina Breast Cancer Study. JAMA 2006, 295, 2492-2502. [CrossRef] [PubMed]

8. Finak, G.; Bertos, N.; Pepin, F.; Sadekova, S.; Souleimanova, M.; Zhao, H.; Chen, H.; Omeroglu, G.; Meterissian, S.; Omeroglu, A.; et al. Stromal gene expression predicts clinical outcome in breast cancer. Nat. Med. 2008, 14, 518-527. [CrossRef]

9. Farmer, P.; Bonnefoi, H.; Anderle, P.; Cameron, D.; Wirapati, P.; Becette, V.; Andre, S.; Piccart, M.; Campone, M.; Brain, E.; et al. A stroma-related gene signature predicts resistance to neoadjuvant chemotherapy in breast cancer. Nat. Med. 2009, 15, 68-74. [CrossRef]

10. DeNardo, D.G.; Brennan, D.J.; Rexhepaj, E.; Ruffell, B.; Shiao, S.L.; Madden, S.F.; Gallagher, W.M.; Wadhwani, N.; Keil, S.D.; Junaid, S.A.; et al. Leukocyte complexity predicts breast cancer survival and functionally regulates response to chemotherapy. Cancer Discov. 2011, 1, 54-67. [CrossRef]

11. Ahn, S.; Cho, J.; Sung, J.; Lee, J.E.; Nam, S.J.; Kim, K.M.; Cho, E.Y. The prognostic significance of tumor-associated stroma in invasive breast carcinoma. Tumour Biol. 2012, 33, 1573-1580. [CrossRef]

12. Koontongkaew, S. The tumor microenvironment contribution to development, growth, invasion and metastasis of head and neck squamous cell carcinomas. J. Cancer 2013, 4, 66-83. [CrossRef] [PubMed]

13. Madar, S.; Goldstein, I.; Rotter, V. 'Cancer associated fibroblasts'-more than meets the eye. Trends Mol. Med. 2013, 19, 447-453. [CrossRef] [PubMed]

14. Erez, N.; Truitt, M.; Olson, P.; Arron, S.T.; Hanahan, D. Cancer-Associated Fibroblasts Are Activated in Incipient Neoplasia to Orchestrate Tumor-Promoting Inflammation in an NF-kappaB-Dependent Manner. Cancer Cell 2010, 17, 135-147. [CrossRef] [PubMed]

15. Soon, P.S.; Kim, E.; Pon, C.K.; Gill, A.J.; Moore, K.; Spillane, A.J.; Benn, D.E.; Baxter, R.C. Breast cancer-associated fibroblasts induce epithelial-to-mesenchymal transition in breast cancer cells. Endocr. Relat. Cancer 2013, 20, 1-12. [CrossRef] [PubMed]

16. Kalluri, R.; Zeisberg, M. Fibroblasts in cancer. Nat. Rev. Cancer 2006, 6, 392-401. [CrossRef]

17. Allen, M.; Louise Jones, J. Jekyll and Hyde: The role of the microenvironment on the progression of cancer. J. Pathol. 2011, 223, 162-176. [CrossRef]

18. Mao, Y.; Keller, E.T.; Garfield, D.H.; Shen, K.; Wang, J. Stromal cells in tumor microenvironment and breast cancer. Cancer Metastasis Rev. 2013, 32, 303-315. [CrossRef]

19. Gonzalez, L.; Eiro, N.; Fernandez-Garcia, B.; Gonzalez, L.O.; Dominguez, F.; Vizoso, F.J. Gene expression profile of normal and cancer-associated fibroblasts according to intratumoral inflammatory cells phenotype from breast cancer tissue. Mol. Carcinog. 2016, 55, 1489-1502. [CrossRef] 
20. Kogan-Sakin, I.; Cohen, M.; Paland, N.; Madar, S.; Solomon, H.; Molchadsky, A.; Brosh, R.; Buganim, Y.; Goldfinger, N.; Klocker, H.; et al. Prostate stromal cells produce CXCL-1, CXCL-2, CXCL-3 and IL-8 in response to epithelia-secreted IL-1. Carcinogenesis 2009, 30, 698-705. [CrossRef]

21. Protti, M.P.; De Monte, L. Cross-talk within the tumor microenvironment mediates Th2-type inflammation in pancreatic cancer. Oncoimmunology 2012, 1, 89-91. [CrossRef]

22. Sotiriou, C.; Neo, S.Y.; McShane, L.M.; Korn, E.L.; Long, P.M.; Jazaeri, A.; Martiat, P.; Fox, S.B.; Harris, A.L.; Liu, E.T. Breast cancer classification and prognosis based on gene expression profiles from a population-based study. Proc. Natl. Acad. Sci. USA 2003, 100, 10393-10398. [CrossRef] [PubMed]

23. Voduc, K.D.; Cheang, M.C.; Tyldesley, S.; Gelmon, K.; Nielsen, T.O.; Kennecke, H. Breast cancer subtypes and the risk of local and regional relapse. J. Clin. Oncol. 2010, 28, 1684-1691. [CrossRef] [PubMed]

24. Gyorffy, B.; Schafer, R. Meta-analysis of gene expression profiles related to relapse-free survival in 1,079 breast cancer patients. Breast Cancer Res. Treat 2009, 118, 433-441. [CrossRef] [PubMed]

25. Tran, B.; Bedard, P.L. Luminal-B breast cancer and novel therapeutic targets. Breast Cancer Res. 2011, 13, 221. [CrossRef] [PubMed]

26. Cancer Genome Atlas, N. Comprehensive molecular portraits of human breast tumours. Nature 2012, 490, 61-70. [CrossRef]

27. Prat, A.; Cheang, M.C.; Martin, M.; Parker, J.S.; Carrasco, E.; Caballero, R.; Tyldesley, S.; Gelmon, K.; Bernard, P.S.; Nielsen, T.O.; et al. Prognostic significance of progesterone receptor-positive tumor cells within immunohistochemically defined luminal A breast cancer. J. Clin. Oncol. 2013, 31, 203-209. [CrossRef]

28. Metzger-Filho, O.; Sun, Z.; Viale, G.; Price, K.N.; Crivellari, D.; Snyder, R.D.; Gelber, R.D.; Castiglione-Gertsch, M.; Coates, A.S.; Goldhirsch, A.; et al. Patterns of Recurrence and outcome according to breast cancer subtypes in lymph node-negative disease: Results from international breast cancer study group trials VIII and IX. J. Clin. Oncol. 2013, 31, 3083-3090. [CrossRef]

29. Jones, J.L.; Walker, R.A. Control of matrix metalloproteinase activity in cancer. J. Pathol. 1997, 183, 377-379. [CrossRef]

30. Egeblad, M.; Werb, Z. New functions for the matrix metalloproteinases in cancer progression. Nat. Rev. Cancer 2002, 2, 161-174. [CrossRef]

31. Chantrain, C.F.; Shimada, H.; Jodele, S.; Groshen, S.; Ye, W.; Shalinsky, D.R.; Werb, Z.; Coussens, L.M.; DeClerck, Y.A. Stromal matrix metalloproteinase-9 regulates the vascular architecture in neuroblastoma by promoting pericyte recruitment. Cancer Res. 2004, 64, 1675-1686. [CrossRef]

32. Pellikainen, J.M.; Ropponen, K.M.; Kataja, V.V.; Kellokoski, J.K.; Eskelinen, M.J.; Kosma, V.M. Expression of matrix metalloproteinase (MMP)-2 and MMP-9 in breast cancer with a special reference to activator protein-2, HER2, and prognosis. Clin. Cancer Res. 2004, 10, 7621-7628. [CrossRef] [PubMed]

33. Vizoso, F.J.; Gonzalez, L.O.; Corte, M.D.; Rodriguez, J.C.; Vazquez, J.; Lamelas, M.L.; Junquera, S.; Merino, A.M.; Garcia-Muniz, J.L. Study of matrix metalloproteinases and their inhibitors in breast cancer. Br. J. Cancer 2007, 96, 903-911. [CrossRef] [PubMed]

34. Xia, Y.; Frangogiannis, N.G. MCP-1/CCL2 as a therapeutic target in myocardial infarction and ischemic cardiomyopathy. Inflamm. Allergy Drug Targets 2007, 6, 101-107. [PubMed]

35. Ueno, T.; Toi, M.; Saji, H.; Muta, M.; Bando, H.; Kuroi, K.; Koike, M.; Inadera, H.; Matsushima, K. Significance of macrophage chemoattractant protein-1 in macrophage recruitment, angiogenesis, and survival in human breast cancer. Clin. Cancer Res. 2000, 6, 3282-3289. [PubMed]

36. Lebrecht, A.; Grimm, C.; Lantzsch, T.; Ludwig, E.; Hefler, L.; Ulbrich, E.; Koelbl, H. Monocyte chemoattractant protein-1 serum levels in patients with breast cancer. Tumour Biol. 2004, 25, 14-17. [CrossRef]

37. Youngs, S.J.; Ali, S.A.; Taub, D.D.; Rees, R.C. Chemokines induce migrational responses in human breast carcinoma cell lines. Int. J. Cancer 1997, 71, 257-266. [CrossRef]

38. Qian, B.Z.; Li, J.; Zhang, H.; Kitamura, T.; Zhang, J.; Campion, L.R.; Kaiser, E.A.; Snyder, L.A.; Pollard, J.W. CCL2 recruits inflammatory monocytes to facilitate breast-tumour metastasis. Nature 2011, 475, 222-225. [CrossRef]

39. Taylor, M.A.; Lee, Y.H.; Schiemann, W.P. Role of TGF-beta and the tumor microenvironment during mammary tumorigenesis. Gene Expr. 2011, 15, 117-132. [CrossRef]

40. Bierie, B.; Moses, H.L. Tumour microenvironment: TGFbeta: The molecular Jekyll and Hyde of cancer. Nat. Rev. Cancer 2006, 6, 506-520. [CrossRef] 
41. Orimo, A.; Gupta, P.B.; Sgroi, D.C.; Arenzana-Seisdedos, F.; Delaunay, T.; Naeem, R.; Carey, V.J.; Richardson, A.L.; Weinberg, R.A. Stromal fibroblasts present in invasive human breast carcinomas promote tumor growth and angiogenesis through elevated SDF-1/CXCL12 secretion. Cell 2005, 121,335-348. [CrossRef]

42. Fernandis, A.Z.; Prasad, A.; Band, H.; Klosel, R.; Ganju, R.K. Regulation of CXCR4-mediated chemotaxis and chemoinvasion of breast cancer cells. Oncogene 2004, 23, 157-167. [CrossRef]

43. Lee, B.C.; Lee, T.H.; Avraham, S.; Avraham, H.K. Involvement of the chemokine receptor CXCR4 and its ligand stromal cell-derived factor 1alpha in breast cancer cell migration through human brain microvascular endothelial cells. Mol. Cancer Res. 2004, 2, 327-338. [PubMed]

44. Kishimoto, H.; Wang, Z.; Bhat-Nakshatri, P.; Chang, D.; Clarke, R.; Nakshatri, H. The p160 family coactivators regulate breast cancer cell proliferation and invasion through autocrine/paracrine activity of SDF-1alpha/CXCL12. Carcinogenesis 2005, 26, 1706-1715. [CrossRef] [PubMed]

45. Kang, H.; Watkins, G.; Parr, C.; Douglas-Jones, A.; Mansel, R.E.; Jiang, W.G. Stromal cell derived factor-1: Its influence on invasiveness and migration of breast cancer cells in vitro, and its association with prognosis and survival in human breast cancer. Breast Cancer Res. 2005, 7, R402-R410. [CrossRef] [PubMed]

46. Smith, M.C.; Luker, K.E.; Garbow, J.R.; Prior, J.L.; Jackson, E.; Piwnica-Worms, D.; Luker, G.D. CXCR4 regulates growth of both primary and metastatic breast cancer. Cancer Res. 2004, 64, 8604-8612. [CrossRef] [PubMed]

47. Tamamura, H.; Hori, A.; Kanzaki, N.; Hiramatsu, K.; Mizumoto, M.; Nakashima, H.; Yamamoto, N.; Otaka, A.; Fujii, N. T140 analogs as CXCR4 antagonists identified as anti-metastatic agents in the treatment of breast cancer. FEBS Lett. 2003, 550, 79-83. [CrossRef]

48. Liang, Z.; Yoon, Y.; Votaw, J.; Goodman, M.M.; Williams, L.; Shim, H. Silencing of CXCR4 blocks breast cancer metastasis. Cancer Res. 2005, 65, 967-971.

49. Liotta, L.A.; Kohn, E.C. The microenvironment of the tumour-host interface. Nature 2001, 411, 375-379. [CrossRef]

50. Talvensaari-Mattila, A.; Paakko, P.; Turpeenniemi-Hujanen, T. Matrix metalloproteinase-2 (MMP-2) is associated with survival in breast carcinoma. Br. J. Cancer 2003, 89, 1270-1275. [CrossRef]

51. Obermair, A.; Kucera, E.; Mayerhofer, K.; Speiser, P.; Seifert, M.; Czerwenka, K.; Kaider, A.; Leodolter, S.; Kainz, C.; Zeillinger, R. Vascular endothelial growth factor (VEGF) in human breast cancer: Correlation with disease-free survival. Int. J. Cancer 1997, 74, 455-458. [CrossRef]

52. Salven, P.; Perhoniemi, V.; Tykka, H.; Maenpaa, H.; Joensuu, H. Serum VEGF levels in women with a benign breast tumor or breast cancer. Breast Cancer Res. Treat. 1999, 53, 161-166. [CrossRef] [PubMed]

53. Manders, P.; Beex, L.V.; Tjan-Heijnen, V.C.; Geurts-Moespot, J.; Van Tienoven, T.H.; Foekens, J.A.; Sweep, C.G. The prognostic value of vascular endothelial growth factor in 574 node-negative breast cancer patients who did not receive adjuvant systemic therapy. Br. J. Cancer 2002, 87, 772-778. [CrossRef] [PubMed]

54. Schmidt-Hansen, B.; Ornas, D.; Grigorian, M.; Klingelhofer, J.; Tulchinsky, E.; Lukanidin, E.; Ambartsumian, N. Extracellular S100A4(mts1) stimulates invasive growth of mouse endothelial cells and modulates MMP-13 matrix metalloproteinase activity. Oncogene 2004, 23, 5487-5495. [CrossRef]

55. Cabezon, T.; Celis, J.E.; Skibshoj, I.; Klingelhofer, J.; Grigorian, M.; Gromov, P.; Rank, F.; Myklebust, J.H.; Maelandsmo, G.M.; Lukanidin, E.; et al. Expression of S100A4 by a variety of cell types present in the tumor microenvironment of human breast cancer. Int. J. Cancer 2007, 121, 1433-1444. [CrossRef] [PubMed]

56. Schmidt-Hansen, B.; Klingelhofer, J.; Grum-Schwensen, B.; Christensen, A.; Andresen, S.; Kruse, C.; Hansen, T.; Ambartsumian, N.; Lukanidin, E.; Grigorian, M. Functional significance of metastasis-inducing S100A4(Mts1) in tumor-stroma interplay. J. Biol. Chem. 2004, 279, 24498-24504. [CrossRef] [PubMed]

57. Jenkinson, S.R.; Barraclough, R.; West, C.R.; Rudland, P.S. S100A4 regulates cell motility and invasion in an in vitro model for breast cancer metastasis. Br. J. Cancer 2004, 90, 253-262. [CrossRef]

58. Ismail, N.I.; Kaur, G.; Hashim, H.; Hassan, M.S. S100A4 overexpression proves to be independent marker for breast cancer progression. Cancer Cell Int. 2008, 8, 12. [CrossRef]

59. Ortiz-Montero, P.; Londono-Vallejo, A.; Vernot, J.P. Senescence-associated IL-6 and IL-8 cytokines induce a self- and cross-reinforced senescence/inflammatory milieu strengthening tumorigenic capabilities in the MCF-7 breast cancer cell line. Cell Commun. Signal 2017, 15, 17. [CrossRef]

60. Salgado, R.; Junius, S.; Benoy, I.; Van Dam, P.; Vermeulen, P.; Van Marck, E.; Huget, P.; Dirix, L.Y. Circulating interleukin-6 predicts survival in patients with metastatic breast cancer. Int. J. Cancer 2003, 103, 642-646. [CrossRef] [PubMed] 
61. Bachelot, T.; Ray-Coquard, I.; Menetrier-Caux, C.; Rastkha, M.; Duc, A.; Blay, J.Y. Prognostic value of serum levels of interleukin 6 and of serum and plasma levels of vascular endothelial growth factor in hormone-refractory metastatic breast cancer patients. Br. J. Cancer 2003, 88, 1721-1726. [CrossRef]

62. Benoy, I.H.; Salgado, R.; Van Dam, P.; Geboers, K.; Van Marck, E.; Scharpe, S.; Vermeulen, P.B.; Dirix, L.Y. Increased serum interleukin-8 in patients with early and metastatic breast cancer correlates with early dissemination and survival. Clin. Cancer Res. 2004, 10, 7157-7162. [CrossRef] [PubMed]

63. Cho, Y.A.; Sung, M.K.; Yeon, J.Y.; Ro, J.; Kim, J. Prognostic role of interleukin-6, interleukin-8, and leptin levels according to breast cancer subtype. Cancer Res. Treat. 2013, 45, 210-219. [CrossRef] [PubMed]

64. Zheng, Y.; Chow, S.O.; Boernert, K.; Basel, D.; Mikuscheva, A.; Kim, S.; Fong-Yee, C.; Trivedi, T.; Buttgereit, F.; Sutherland, R.L.; et al. Direct crosstalk between cancer and osteoblast lineage cells fuels metastatic growth in bone via auto-amplification of IL-6 and RANKL signaling pathways. J. Bone Miner. Res. 2014, 29, 1938-1949. [CrossRef] [PubMed]

65. Li, J.; Li, F.; Wang, H.; Wang, X.; Jiang, Y.; Li, D. Wortmannin reduces metastasis and angiogenesis of human breast cancer cells via nuclear factor-kappaB-dependent matrix metalloproteinase- 9 and interleukin- 8 pathways. J. Int. Med. Res. 2012, 40, 867-876. [CrossRef]

66. Pravtcheva, D.D.; Wise, T.L. Metastasizing mammary carcinomas in H19 enhancers-Igf2 transgenic mice. J. Exp. Zool. 1998, 281, 43-57. [CrossRef]

67. Pollak, M. Insulin and insulin-like growth factor signalling in neoplasia. Nat. Rev. Cancer 2008, 8, 915-928. [CrossRef] [PubMed]

68. Li, B.; Tsao, S.W.; Chan, K.W.; Ludwig, D.L.; Novosyadlyy, R.; Li, Y.Y.; He, Q.Y.; Cheung, A.L. Id1-induced IGF-II and its autocrine/endocrine promotion of esophageal cancer progression and chemoresistance-implications for IGF-II and IGF-IR-targeted therapy. Clin. Cancer Res. 2014, 20, 2651-2662. [CrossRef] [PubMed]

69. Gallagher, E.J.; LeRoith, D. Minireview: IGF, Insulin, and Cancer. Endocrinology 2011, 152, $2546-2551$. [CrossRef] [PubMed]

70. Salisbury, T.B.; Morris, G.Z.; Tomblin, J.K.; Chaudhry, A.R.; Cook, C.R.; Santanam, N. Aryl hydrocarbon receptor ligands inhibit igf-ii and adipokine stimulated breast cancer cell proliferation. ISRN Endocrinol. 2013, 2013, 104850. [CrossRef] [PubMed]

71. Tomblin, J.K.; Salisbury, T.B. Insulin like growth factor 2 regulation of aryl hydrocarbon receptor in MCF-7 breast cancer cells. Biochem. Biophys. Res. Commun. 2014, 443, 1092-1096. [CrossRef]

72. Hamilton, N.; Marquez-Garban, D.; Mah, V.; Fernando, G.; Elshimali, Y.; Garban, H.; Elashoff, D.; Vadgama, J.; Goodglick, L.; Pietras, R. Biologic roles of estrogen receptor-beta and insulin-like growth factor-2 in triple-negative breast cancer. Biomed. Res. Int. 2015, 2015, 925703. [CrossRef] [PubMed]

73. Tominaga, K.; Shimamura, T.; Kimura, N.; Murayama, T.; Matsubara, D.; Kanauchi, H.; Niida, A.; Shimizu, S.; Nishioka, K.; Tsuji, E.I.; et al. Addiction to the IGF2-ID1-IGF2 circuit for maintenance of the breast cancer stem-like cells. Oncogene 2017, 36, 1276-1286. [CrossRef] [PubMed]

74. Gui, Y.; Aguilar-Mahecha, A.; Krzemien, U.; Hosein, A.; Buchanan, M.; Lafleur, J.; Pollak, M.; Ferrario, C.; Basik, M. Metastatic Breast Carcinoma-Associated Fibroblasts Have Enhanced Protumorigenic Properties Related to Increased IGF2 Expression. Clin. Cancer Res. 2019, 25, 7229-7242. [CrossRef] [PubMed]

75. Gronbaek, H.; Flyvbjerg, A.; Mellemkjaer, L.; Tjonneland, A.; Christensen, J.; Sorensen, H.T.; Overvad, K. Serum insulin-like growth factors, insulin-like growth factor binding proteins, and breast cancer risk in postmenopausal women. Cancer Epidemiol. Biomark. Prev. 2004, 13, 1759-1764.

76. Peiro, G.; Adrover, E.; Sanchez-Tejada, L.; Lerma, E.; Planelles, M.; Sanchez-Paya, J.; Aranda, F.I.; Giner, D.; Gutierrez-Avino, F.J. Increased insulin-like growth factor-1 receptor mRNA expression predicts poor survival in immunophenotypes of early breast carcinoma. Mod. Pathol. 2011, 24, 201-208. [CrossRef] [PubMed]

77. Gee, J.M.; Robertson, J.F.; Gutteridge, E.; Ellis, I.O.; Pinder, S.E.; Rubini, M.; Nicholson, R.I. Epidermal growth factor receptor/HER2/insulin-like growth factor receptor signalling and oestrogen receptor activity in clinical breast cancer. Endocr Relat Cancer 2005, 12 (Suppl. 1), S99-S111. [CrossRef]

78. Chan, T.W.; Pollak, M.; Huynh, H. Inhibition of insulin-like growth factor signaling pathways in mammary gland by pure antiestrogen ICI 182,780. Clin. Cancer Res. 2001, 7, 2545-2554. 
79. Singer, C.F.; Rasmussen, A.; Lippman, M.E.; Cullen, K.J. Coexpression of stromelysin-3 and insulin-like growth factor II in tumors of ectodermal, mesodermal, and endodermal origin: Indicator of a fetal cell phenotype. J. Clin. Endocrinol. Metab. 1997, 82, 1917-1922. [CrossRef]

Publisher's Note: MDPI stays neutral with regard to jurisdictional claims in published maps and institutional affiliations.

(C) 2020 by the authors. Licensee MDPI, Basel, Switzerland. This article is an open access article distributed under the terms and conditions of the Creative Commons Attribution (CC BY) license (http://creativecommons.org/licenses/by/4.0/). 